\title{
EFFECTS OF STRUCTURAL INTEGRITY ON IMPROVING THE RESISTANCE TO DYNAMIC LOADS
}

The paper deals with the approaches to the dynamic response analysis when non-linear response of the structure including its partial damage is expected. This concerns the building and other structures executed near transport lines and possibly subjected to seismic effects from transport or earthquakes. Seismic response is here analysed under the action of near field earthquake that was considered and applied as $6 D O F$ seismic input and 2DOF seismic input. A typical reinforced concrete frame with masonry infills was chosen as the prototype for the experimental tests and next analysis. Two storey one bay 1:1 model was tested on a large shaking table with sequentially increasing intensity of seismic input. The specimen was designed according to the rules of Eurocode 8 and the masonry infill was strengthened with horizontal polymer grids placed in prescribed bed joints. The non-linear behaviour is analysed in view of pushover analysis approach and limits of interstorey drift. General behaviour of the analysed frame showed reasonable seismic resistance that was supported by sufficient integrity and limited cracks appearance.

Keywords: space seismic input, near field earthquake, polymer grids, interstorey drift, R/C frame, masonry infills, seismic resistance capacity

\section{Introduction}

The response spectra approach became a popular tool for the structural seismic response analysis and design. Both advantages and disadvantages of response spectra characteristics are well known, the simplicity of calculations is pushing designers and researchers to utilise the extended related application tools as pushover analysis, non-linear seismic response analysis in time domain, combined with the verification of deformations and stresses. If the deformation and stress states do not conform the safety requirements, the key action is the application of the appropriately chosen additional materials and measures that support the enhanced dynamic resistance of the structure against transport, accidental and/or seismic effects, see e.g. [Anicic et al., 1990], [Colombo and Negro, 2000], [Paulay and Priestley, 1992].

Structures in seismic regions shall be designed and constructed in such a way that two basic requirements are met, each with an adequate degree of reliability. This concerns the no-collapse requirement and damage limitation requirement (EN 1998-1: 2004).

To meet the no-collapse requirement, the structure shall be designed and constructed to withstand the design seismic action without local or global collapse, thus retaining its structural integrity and a residual load bearing capacity after a seismic event. The design seismic action is expressed in terms of the reference seismic action associated with a reference probability of exceedance $P_{N C R}$, in 50 years (usually $10 \%$ ) or a reference return period $T_{N C R}$ (usually 475 years) and completed with importance factor of an analysed structure.
To meet the damage limitation requirement the structure shall be designed and constructed to withstand a seismic action having a larger probability of occurrence than the design seismic action, without the occurrence of damage and the associated limitations of use, the costs of which would be disproportionately high in comparison with the costs of the structure itself. The seismic action to be taken into account has a probability of exceedance $P_{D L R}$ in 10 years (usually $10 \%$ ) and a return period $T_{D L R}$ (usually 95 years).

Since the seismic performance of a structure is largely dependent on the behaviour of its critical regions or elements, the detailing of the structure in general and of these regions or elements in particular, shall be such as to maintain the capacity to transmit the necessary forces and to dissipate energy under cyclic conditions. The resistance and energy-dissipation capacity to be assigned to the structure are related to the extent to which its non-linear response is to be exploited [Juhásová, 1991], [Hájek, 1994].

The tested and analysed $\mathrm{R} / \mathrm{C}$ frame model was subjected to the sequence of seismic inputs with increasing intensity of acting seismic motion. The near field earthquake record was used as a base for shaking table tests.

\section{Properties of applied near field earthquake motion}

The near field earthquakes are characterised by short duration, large initial amplitude of acceleration and higher vertical component that is equal or higher than horizontal ones. The applied

\footnotetext{
* Emília Juhásová

Institute of Construction and Architecture Slovak Academy of Sciences, Dúbravská cesta 9, 84503 Bratislava, Slovakia, E-mail:usarjuha@savba.sk
} 
seismic input used time history of near field earthquake recorded at Nocera during the Central Italy 1997 Umbria earthquake. This record contains high amplitudes of accelerations (nearly $0.5 \mathrm{~g}$ in each direction). It was recorded at a distance about $11 \mathrm{~km}$ from the epicentre. The magnitude $M w=6.0$. The general features of this record show that the large amount of energy comes during the first 5-6 sec. The original record lasted $45 \mathrm{sec}$, but for tests and analysis purposes it was sufficient to consider the length of $25 \mathrm{sec}$. The applied time histories of input accelerations and displacements include also calculated rotations roll, pitch, yaw, see Figs. 1 and 2 [Juhásová et al., 2000, 2004]. The response spectra for damping $2 \%$ and $5 \%$ are in Figs. 3 and 4.

In general, an actual seismic ground motion is interconnected with wave fields that consist of components of different frequencies and waves lengths. Some structures might be sensitive to spatial varying vertical excitation; a vertical ground motion propagating in any horizontal direction is expected to promote a rocking of the structure, concurrent with the rocking provided by the horizontal excitation along that direction. The contribution of horizontal ground motions to torsion seismic input either increases the torsion response of asymmetrical structures or creates torsion
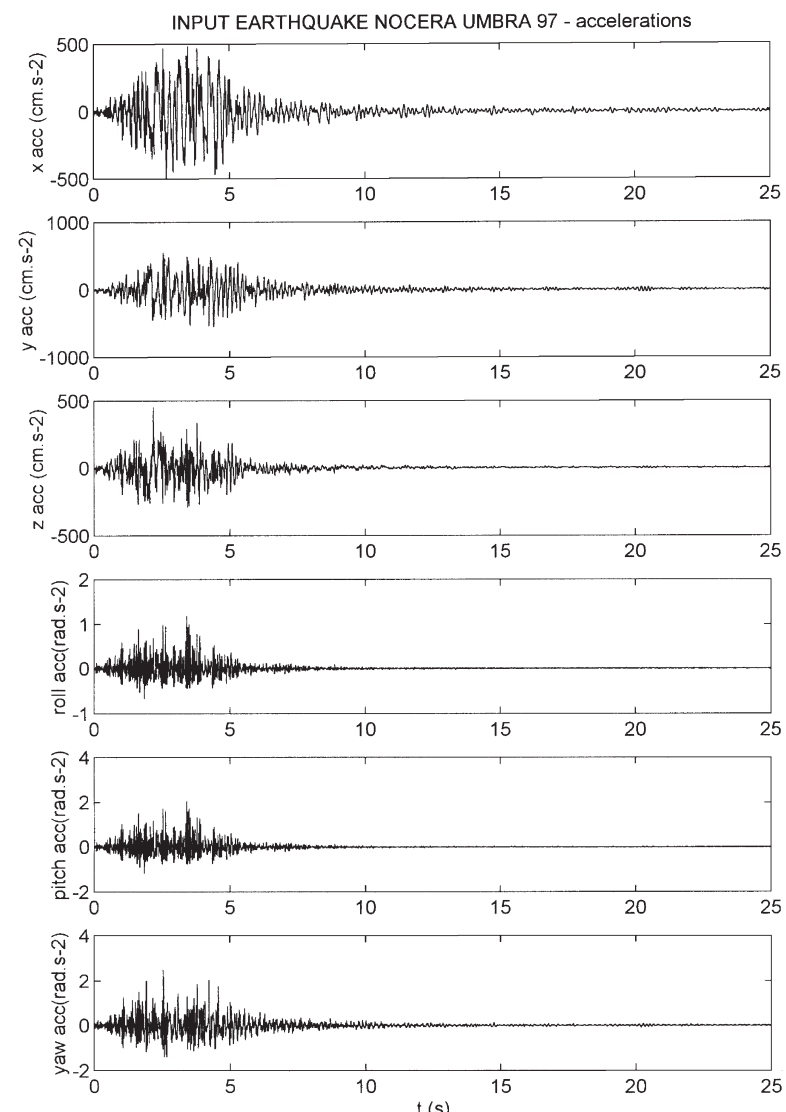

Fig. 1 Translate and rotation acceleration time histories related to

Umbria, Italy 1997 earthquake, Nocera record, $d t=0.005 \mathrm{~s}$; used as the seismic input for shaking table tests response in case of symmetrical structures. The rotation input acting at the ground level arrives with a phase shift in relation to respective translate input. Both time histories and response spectra are influenced by this phase shift and the frequency value. The calculated rotation input time histories could be used in those cases when no direct information about rotation seismic motion of the ground exists. However, lately new sensors and instruments of different type were developed for direct measurement of rotation motions. This represents the promise for the future in the form of actual rotation seismic motions recorded during a seismic event [Juhásová, 1999, 2004].
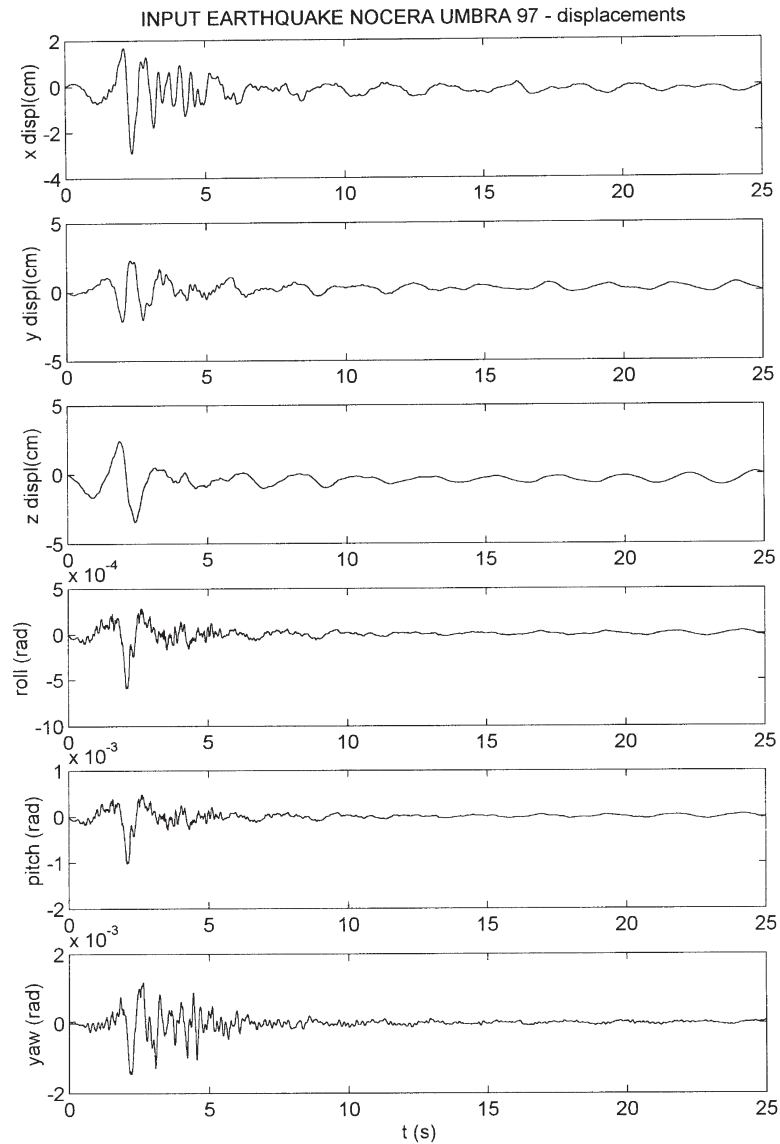

Fig. 2 Displacement and rotation time histories related to Umbria, Italy 1997 earthquake, Nocera record, $d t=0.005 \mathrm{~s}$; used as the seismic input for shaking table tests

\section{Full scale reinforced concrete frame specimen tested on the shaking table}

More realistic data on the behaviour of $\mathrm{R} / \mathrm{C}$ frame structures can be obtained on actual structures or on large scale models. A large 1:1 R/C one bay two storey frame model with solid brick masonry infills was tested on the shaking table. The seismic loading was introduced in the sequence of increasing intensity modelled through the input specified in Figs. 1 to 4 . The frame system was 

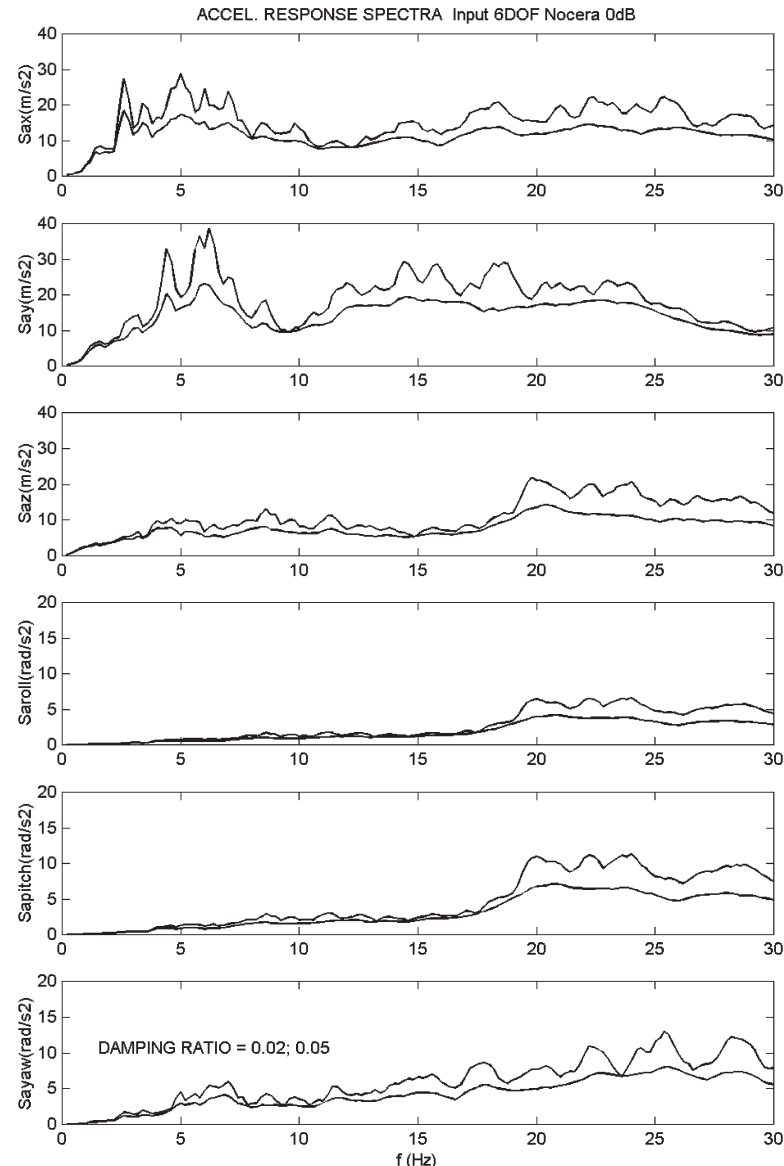

Fig. 3 Acceleration response spectra of Nocera 1997 seismic input

\section{SECTION FIRST FLOOR}

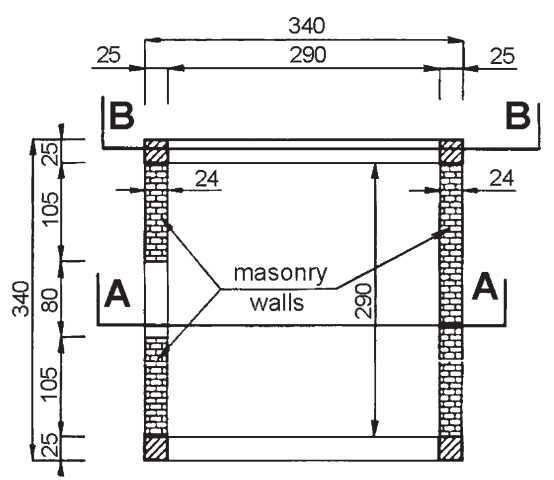

Fig. $5 \mathrm{R} / \mathrm{C}$ frame model with masonry infills - horizontal sections designed according to the rules of Eurocode 8 with doubled stirrups. The dimensions of the model and its reinforcement are given in Figs. 5 to 7.

The model was constructed as symmetrical in $y$ direction and asymmetrical in $x$ direction. Its dimensions in plan were $3.5 \times$
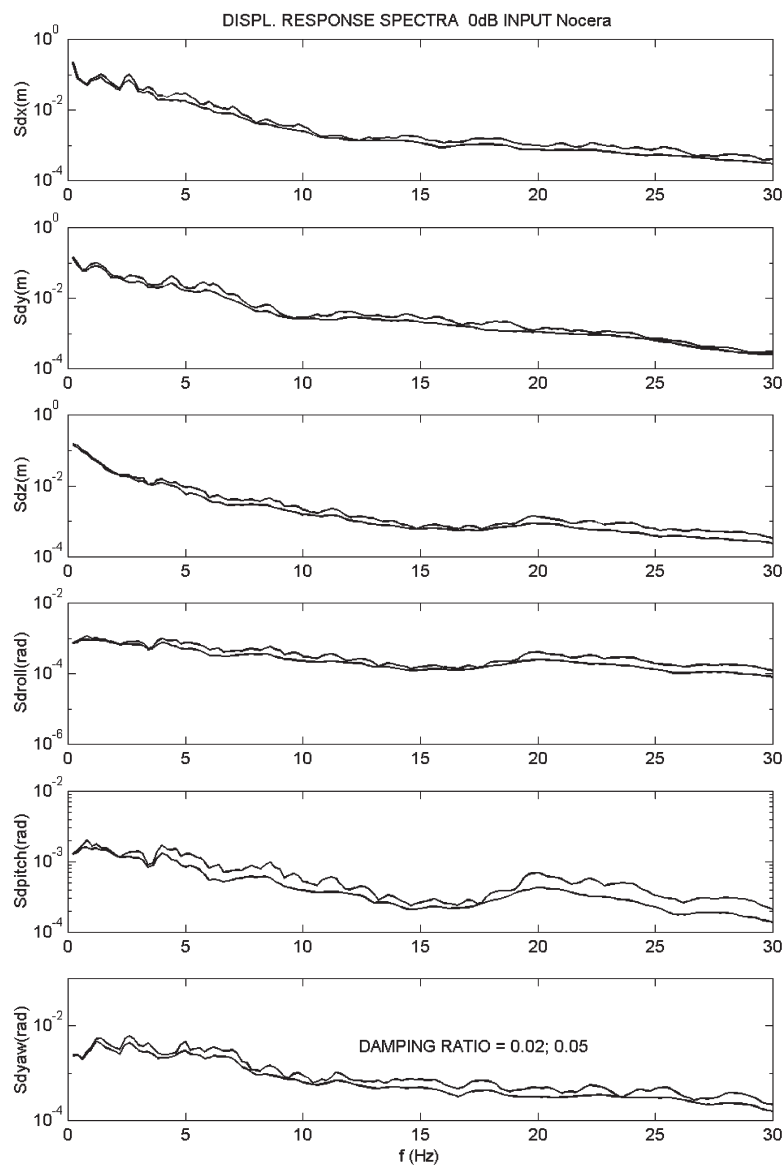

Fig. 4 Displacement response spectra of Nocera 1997 seismic input

\section{SECTION SECOND FLOOR}

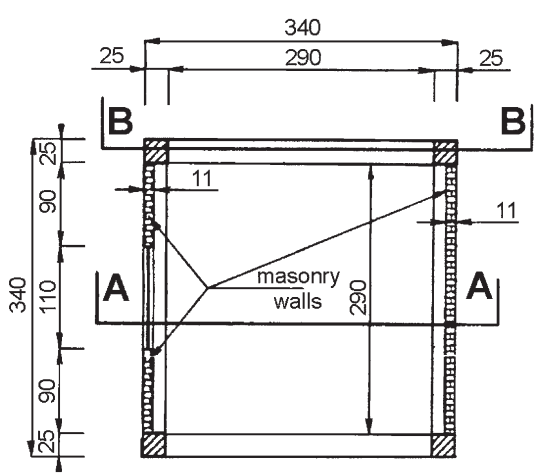

$\times 3.5 \mathrm{~m}$, height was $5.9 \mathrm{~m}$. R/C columns were of square cross section $0.25 \times 0.25 \mathrm{~m}$, girders $0.25 \times 0.30 \mathrm{~m}$, floor slabs were $10 \mathrm{~cm}$ thick. Two opposite masonry walls were constructed from solid bricks of thickness $24 \mathrm{~cm}$ in the first storey and $11 \mathrm{~cm}$ in the second storey. The front wall had a door in the first storey and a window in a second storey, the back wall was full. Lime-cement 
SECTION A-A

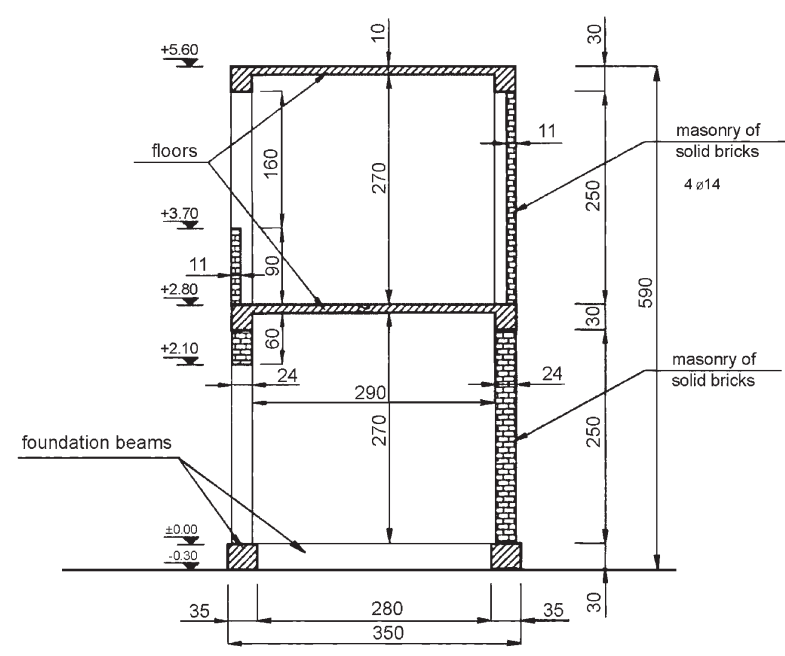

FRONT SIZE

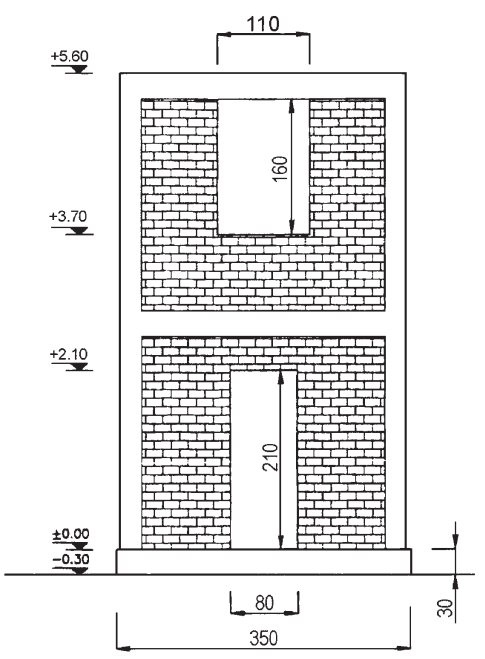

Fig. 6 R/C frame model with masonry infills - vertical section and front elevation

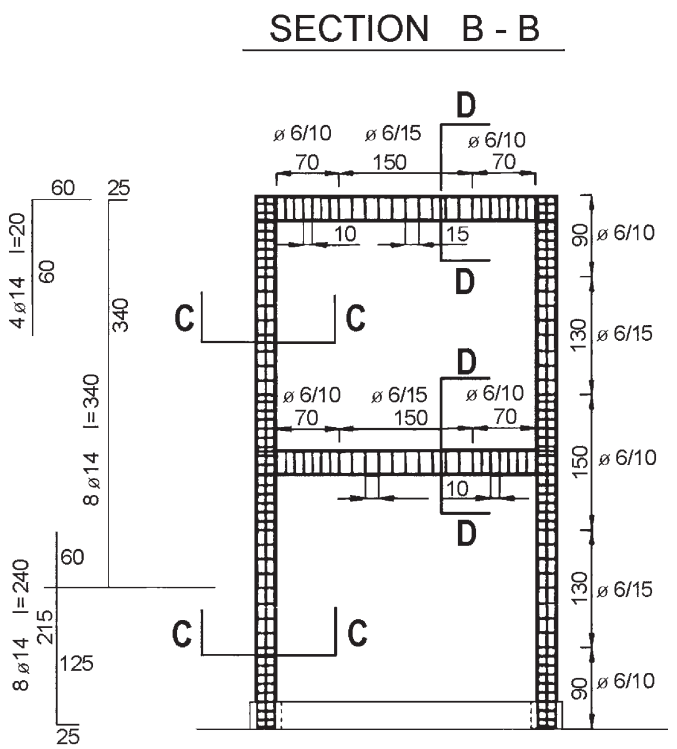

SECTION C-C
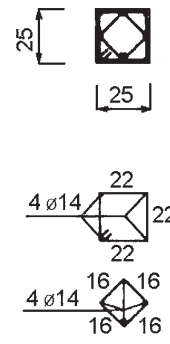

$\mathrm{C} 1,2,3,4$

$8 ø 14$

Stirrups $\varnothing 6 / 10(15) L=98$

Stirrups $\varnothing 6 / 10(15) \mathrm{L}=74$

hor $(0.60 \mathrm{~cm})$ Stirrups $ø 6 / 10$

Stirrups $ø 6\left(\begin{array}{l}\text { PLACED IN } \\ \text { THE SAME SECTION }\end{array}\right)$

Fig. 7 R/C frame model with masonry infills - steel reinforcement

mortar was used in masonry together with polymer grid Tensar SS20 reinforcement in horizontal bed joints, applied in each fifth row. The polymer grids, with slender ribs and solid integrated joints, inserted in the bed layers are uniformly distributing the tensile stresses and by the sandwich effect any stress concentration is prevented. The polymer grids are effective prevailingly in tension and to some degree in shear [Sofronie et al., 2003], [Bairrao et al., 2006]. 64 channel data acquisition system was used to follow accelerations, strains and displacements in appropriately chosen points. The registration of data ran continuously in time with sampling frequency $200 \mathrm{~Hz}$. The view of model with position of sensors is in Fig. 8.

\section{Procedure of test and main test results}

The tests comprised impact tests, sweep sine tests and earthquake like $x, y, z, \theta x, \theta y$ and $\theta z$ common excitation with increasing intensity of seismic input [Juhásová, 1999, 2004]. However, the short duration of strong earthquake phase did not allow to develop low cycle fatigue like behaviour with development of hysteresis loops in critical sections of a system. The strength in critical points was decisive and redistribution of stresses during the response was affected both by input and natural modes of vibration. Table 1 gives the schedule of applied test steps. 


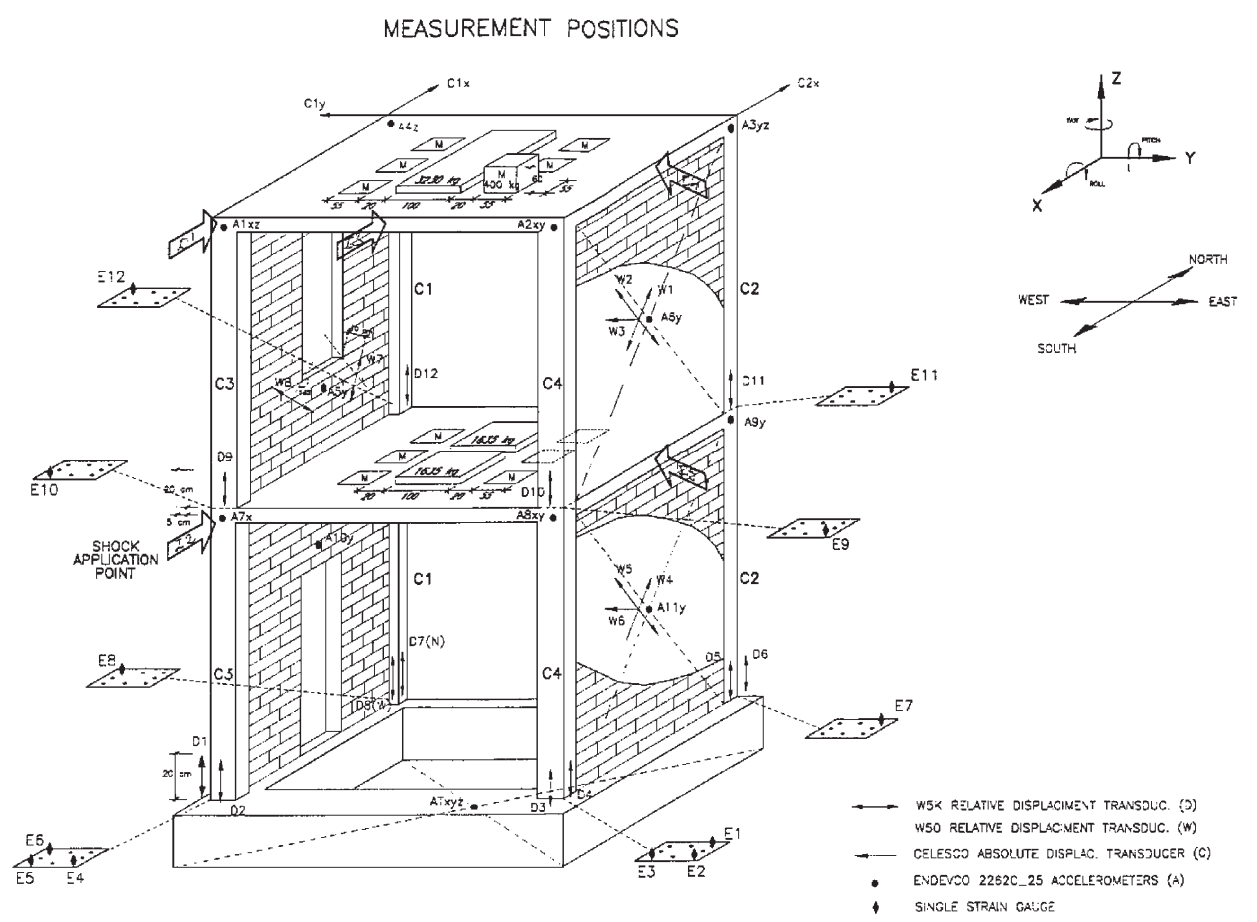

Fig. 8 Position of sensors on tested R/C frame with masonry infills

Review of applied test steps - R/C frame with masonry infills

Table 1

\begin{tabular}{|c|c|c|c|c|c|c|c|c|c|}
\hline $\begin{array}{l}\text { Test } \\
\text { No. }\end{array}$ & Loading & $\begin{array}{c}\max a T x \\
(\mathrm{~g})\end{array}$ & $\begin{array}{c}\max \text { aTy } \\
(\mathrm{g})\end{array}$ & $\begin{array}{c}\max \mathrm{aT} z \\
(\mathrm{~g})\end{array}$ & $\begin{array}{l}\text { Test } \\
\text { No. }\end{array}$ & Loading & $\begin{array}{c}\max a T x \\
(\mathrm{~g})\end{array}$ & $\begin{array}{c}\max a \mathrm{aT} y \\
(\mathrm{~g})\end{array}$ & $\begin{array}{c}\max a T z \\
(\mathrm{~g})\end{array}$ \\
\hline $\mathrm{T} 1$ & Impact I1, table down & - & - & - & $\mathrm{T} 18$ & seis. $-6 \mathrm{~dB} 6 \mathrm{DOF}$ & - & - & - \\
\hline $\mathrm{T} 2$ & Impact I2, table down & - & - & - & T19 & seis. $-3 \mathrm{~dB} 6 \mathrm{DOF}$ & 0.567 & 0.585 & 0.407 \\
\hline $\mathrm{T} 3$ & Impact I3, table down & - & - & - & $\mathrm{T} 20$ & seis. $0 \mathrm{~dB} 6 \mathrm{DOF}$ & 0.867 & 0.797 & 0.706 \\
\hline $\mathrm{T} 4$ & Impact I4, table down & - & - & - & $\mathrm{T} 21$ & seis. $2 \mathrm{~dB}(\mathrm{e}) 6 \mathrm{DOF}$ & 0.087 & 0.103 & 0.095 \\
\hline T5 & Impact I5, table down & - & - & - & $\mathrm{T} 22$ & seis. $2 \mathrm{~dB} \mathrm{r} 6 \mathrm{DOF}$ & 0.945 & 0.986 & 1.156 \\
\hline $\mathrm{T} 6$ & sweep sine $x$ & - & - & - & $\mathrm{T} 23$ & seis. $3 \mathrm{~dB} 6 \mathrm{DOF}$ & 1.124 & 1.063 & 0.932 \\
\hline $\mathrm{T} 7$ & sweep sine $x$ & 0.0114 & 0.0084 & 0.0051 & $\mathrm{~T} 24$ & seis. 3dB r 6DOF & 0.990 & 1.142 & 0.518 \\
\hline $\mathrm{T} 8$ & sweep sine $y$ & 0.0039 & 0.0112 & 0.0018 & $\mathrm{~T} 25$ & seis. 4dB 6DOF & 1.132 & 1.270 & 0.600 \\
\hline T9 & Impact I3 table up & - & - & - & $\mathrm{T} 26$ & seis. $0 \mathrm{~dB} 2 \mathrm{DOF}$ & 0.693 & 0.068 & 0.356 \\
\hline $\mathrm{T} 10$ & Impact I3 table up & - & - & - & $\mathrm{T} 27$ & seis. $5 \mathrm{~dB} 2 \mathrm{DOF}$ & - & - & - \\
\hline T11 & Impact I3 table down & - & - & - & $\mathrm{T} 28$ & seis. $6 \mathrm{~dB} 2 \mathrm{DOF}$ & 1.0732 & 0.132 & 0.845 \\
\hline $\mathrm{T} 12$ & sweep sine $z$ & 0.0086 & 0.0154 & 0.0118 & $\mathrm{~T} 29$ & seis. $7 \mathrm{~dB} 2 \mathrm{DOF}$ & - & - & - \\
\hline $\mathrm{T} 13$ & seis. $-18 \mathrm{~dB} 6 \mathrm{DOF}$ & - & - & - & $\mathrm{T} 30$ & seis. $8 \mathrm{~dB} 2 \mathrm{DOF}$ & 2.412 & 0.144 & 1.147 \\
\hline T14 & seis. $-15 \mathrm{~dB} 6 \mathrm{DOF}$ & - & - & - & $\mathrm{T} 31$ & sweep sine $x$ & 0.0118 & 0.0014 & 0.0014 \\
\hline $\mathrm{T} 15$ & seis. $-18 \mathrm{~dB} 6 \mathrm{DOF}$ & - & - & - & $\mathrm{T} 32$ & sweep sine $y$ & 0.0018 & 0.0112 & 0.0020 \\
\hline T16 & seis. $-12 \mathrm{~dB} 6 \mathrm{DOF}$ & - & - & - & $\mathrm{T} 33$ & sweep sine $z$ & 0.0059 & 0.0098 & 0.0122 \\
\hline $\mathrm{T} 17$ & seis. $-9 \mathrm{~dB} 6 \mathrm{DOF}$ & - & - & - & & & & & \\
\hline
\end{tabular}

The impact loading was applied in appropriately chosen points denoted in Fig. 8 by I1, I2, I3, I4 and I5. 6DOF seismic input was introduced during the tests T19 to T25. Next tests T26 to T30 introduced only 2DOF seismic input $(x+$ pitch), thus securing the higher excitation in the direction of infill walls. Representative data from tests are in Tables 2 to 4 . 
Measured and recalculated natural frequencies of tested $\mathrm{R} / \mathrm{C}$ frame with masonry infills

\begin{tabular}{|l|c|c|c|c|c|c|}
\hline Natural frequencies (Hz) & $(x-\theta)_{1}$ & $(x-\theta)_{2}$ & $(\theta-x)_{1}$ & $(\theta-x)_{2}$ & $y_{1}$ & $y_{2}$ \\
\hline Impact(1) table down & 8.3 & 27 & 13.1 & 37 & 3.5 & 10.3 \\
\hline Impact(2) table up & 12.0 & 27.5 & & & & \\
\hline Sweep sine $x$ & 11.4 & 24.4 & 12.8 & $37 ?$ & 2.9 & 9 \\
\hline Sweep sine $y$ & & & & & 2.75 & 9 \\
\hline Seismic Test 19 & 4.78 & & 6.24 & 9.76 & 2.70 & 7.18 \\
\hline FEMA 273 Test 19 ini & 4.41 & & & & 2.35 & \\
\hline FEMA 273 Test 25 aft. & 3.92 & & & & 1.80 & \\
\hline Sweep sine $x$ after Test 30 & 2.46 & 7.44 & 5.39 & 8.24 & & \\
\hline Sweep sine $y$ after Test 30 & & & & & 1.62 & 5.68 \\
\hline Total mass $=31.46$ tons & & & \\
\hline
\end{tabular}

On the basis of the obtained experimental results it is worth to pick up following observations:

a) The experimental dynamic identification of the model was successfully completed. The impact and sweep sine tests served directly for dynamic identification purposes. The seismic tests enable to recognize the response and damage development. With increasing intensity of test the $\mathrm{R} / \mathrm{C}$ frame and masonry stiffness were decreasing. Sweep sine test in $z$-direction gave the floor slabs natural frequencies of values $17 \mathrm{~Hz}$ for second storey and $19 \mathrm{~Hz}$ for the first storey.

b) The structural system is symmetrical in $y$-direction, where both natural frequencies were clearly identified. In $x$ direction the asymmetry of infills exists and coupled vibration $x-\theta$ was identified as expected. Next contribution came from boundary conditions. There exists evident difference between the impact tests in the case of shaking table down - in parking position and in operating - up position of the shaking table. With increasing seismic input the natural frequencies were decreasing. At a low level of excitation the damping was very low. Especially in $y$-direction the damping ratio reached during sweep sine test only $1.5-2.0 \%$. However, it was increasing at a higher seismic input and due to the effect of partial damage. c) The asymmetrical structure with a symmetrical reinforced concrete frame showed a considerable contribution of reinforced infill masonry to the total stiffness and strength. Having general earthquake like 6DOF seismic input, the yielding appeared firstly in the steel reinforcement of columns and it was followed by separation in the upper horizontal and vertical connections between the frame and infill masonry. The result of this process aimed at separate cantilever like vibration of left masonry panel in the second storey of the model. It should be expected that during the longer stage of extreme seismic input the out of plane failure of masonry would appear as the first one. The view of cracks in and near $\mathrm{R} / \mathrm{C}$ frame joints can be seen in Figs. 9 to 11. Fig. 12 presents the cracks in masonry walls at the end of the tests (after T30). Actually, the introduced seismic excitation is considerably above the levels of seismic inputs usually expected during the seismic events.

The obtained results suggest that the applied technique provided the system with higher seismic resistance with uniformly distributed seismic capacity through the structure since the beginning of the model failure.

The interstorey drift is another characteristic that should be treated in relation to the non-collapse and damage limitation requirements (see e.g. EN 1998-1: 2004). The values of this characteristic are in Table 4, as they were recalculated from the experimental data. For reference points position 1, 2, 3, 7, 8, 9, see Fig. 8 .

For the non-collapse requirement the second-order effects ( $P-\Delta$ effects) need not be taken into account if the following condition is fulfilled in all the storeys:

$$
\delta=\frac{P_{t o t} d_{r}}{V_{t o t} h} \leq 0.10
$$

where

$\delta \quad$ is the interstorey drift sensitivity coefficient;

$P_{t o t}$ is the total gravity load at and above the storey considered in the seismic design situation;

$d_{r}$ is the design interstorey drift, evaluated as the difference of the average lateral displacements ds at the top and bottom of the storey;

$V_{\text {tot }}$ is the total seismic storey shear; and

$h$ is the interstorey height.

Chosen measured extremes in seismic response of the tested specimen

Table 3

\begin{tabular}{|c|c|c|c|c|}
\hline Test N. & Input $(\mathrm{dB})$ & Input (DOF) & Milistrains (steel) & $\begin{array}{l}\text { Relative deflections (concrete) } \\
(\mathrm{mm}) \text { reference length }=200 \mathrm{~mm}\end{array}$ \\
\hline 19 & $-3 \mathrm{~dB}$ & $6 \mathrm{DOF}$ & $E 1=1.37$ & $\mathrm{D} 1=0.26 \mathrm{~mm} ; \mathrm{D} 4=0.27 \mathrm{~mm}$ \\
\hline 20 & $0 \mathrm{~dB}$ & $6 \mathrm{DOF}$ & $E 1>2 ;$ E1res $=1.48$ & $\mathrm{D} 1=0.59 \mathrm{~mm} ; \mathrm{D} 4=0.33 \mathrm{~mm}$ \\
\hline 21 & $2 \mathrm{~dB}$ & $6 \mathrm{DOF}$ & E1 $>4-$ broken; E7 $>5 ;$ E7res $=3.9 ;$ & $\mathrm{D} 4=2.13 \mathrm{~mm}$ \\
\hline 22 & $2 \mathrm{~dB}$ rep. & $6 \mathrm{DOF}$ & $E 7=11.9 ;$ E7res $=7.6 ;$ E2 $=4 ;$ E2res $=0.8$ & $\mathrm{D} 4=2.2 \mathrm{~mm}$ \\
\hline 25 & $4 \mathrm{~dB}$ & $6 \mathrm{DOF}$ & $E 6=6.3 ;$ E6res $=1.9$ & $\mathrm{D} 5=2.1 \mathrm{~mm} ; \mathrm{D} 8=2 \mathrm{~mm}$ \\
\hline 30 & $8 \mathrm{~dB}$ & 2DOF & - & $\mathrm{D} 11=1.6 \mathrm{~mm}$ \\
\hline
\end{tabular}




\begin{tabular}{|c|c|c|c|c|c|c|c|}
\hline \multicolumn{4}{|c|}{ Test $19, \max$ a $T x=0.57 \mathrm{~g}, 6 \mathrm{DOF} ; h_{s}=2.8 \mathrm{~m}$} & \multicolumn{4}{|c|}{ Test $19, \max$ aTy $=0.58 \mathrm{~g}, 6 \mathrm{DOF} ; h_{s}=2.8 \mathrm{~m}$} \\
\hline$\Delta 1-7 x$ & $\Delta 2-8 x$ & $\Delta 7-T x$ & $\Delta 8-T x$ & $\Delta 2-8 y$ & $\Delta 3-9 y$ & $\Delta 8-T y$ & $\Delta 9-T y$ \\
\hline $9.32 \mathrm{~mm}$ & $7.41 \mathrm{~mm}$ & $9.89 \mathrm{~mm}$ & $5.38 \mathrm{~mm}$ & $13.85 \mathrm{~mm}$ & $13.74 \mathrm{~mm}$ & $14.65 \mathrm{~mm}$ & $19.77 \mathrm{~mm}$ \\
\hline $0.33 \%$ & $0.26 \%$ & $0.35 \%$ & $0.19 \%$ & $0.49 \%$ & $0.49 \%$ & $0.52 \%$ & $0.71 \%$ \\
\hline \multicolumn{4}{|c|}{ Test $25, \max$ a $T x=1.13 \mathrm{~g}, 6 \mathrm{DOF} ; h_{s}=2.8 \mathrm{~m}$} & \multicolumn{4}{|c|}{ Test 25, max aTy $=1.27 \mathrm{~g}, 6 \mathrm{DOF} ; h_{s}=2.8 \mathrm{~m}$} \\
\hline$\Delta 1-7 x$ & $\Delta 2-8 x$ & $\Delta 7-T x$ & $\Delta 8-T x$ & $\Delta 2-8 y$ & $\Delta 3-9 y$ & $\Delta 8-T y$ & $\Delta 9-T y$ \\
\hline $20.89 \mathrm{~mm}$ & $23.65 \mathrm{~mm}$ & $17.25 \mathrm{~mm}$ & $15.40 \mathrm{~mm}$ & $51.03 \mathrm{~mm}$ & $43.42 \mathrm{~mm}$ & $53.47 \mathrm{~mm}$ & $45.39 \mathrm{~mm}$ \\
\hline $0.75 \%$ & $0.84 \%$ & $0.62 \%$ & $0.55 \%$ & $1.82 \%$ & $1.55 \%$ & $1.91 \%$ & $1.62 \%$ \\
\hline \multicolumn{4}{|c|}{ Test $30, \max$ a $T x=2.41 \mathrm{~g}, 2 \mathrm{DOF} ; h_{s}=2.8 \mathrm{~m}$} & \multicolumn{4}{|c|}{ Test $30, \max$ aTy $=0.14 \mathrm{~g}, 2 \mathrm{DOF} ; h_{s}=2.8 \mathrm{~m}$} \\
\hline$\Delta 1-7 x$ & $\Delta 2-8 x$ & $\Delta 7-T x$ & $\Delta 8-T x$ & $\Delta 2-8 y$ & $\Delta 3-9 y$ & $\Delta 8-T y$ & $\Delta 9-T y$ \\
\hline $51.05 \mathrm{~mm}$ & $38.61 \mathrm{~mm}$ & $32.88 \mathrm{~mm}$ & $31.65 \mathrm{~mm}$ & $11.79 \mathrm{~mm}$ & $8.02 \mathrm{~mm}$ & $9.48 \mathrm{~mm}$ & $7.70 \mathrm{~mm}$ \\
\hline $1.82 \%$ & $1.38 \%$ & $1.17 \%$ & $1.13 \%$ & $0.42 \%$ & $0.29 \%$ & $0.34 \%$ & $0.27 \%$ \\
\hline
\end{tabular}

The values of $\delta$ determined from the experiment maximum drifts in the first storey are:

for y-direction: $\delta=31.46 \times 9.81 \times 0.05347 /(180 \times 2.8)=0.0327$; for x-direction: $\delta=31.46 \times 9.81 \times 0.05105 /(340 \times 2.8)=0.0165$, which are lower than the limit in Eq. (1).

Thus, the values from Table 4 and Fig. 16 suggest that for similar low $\mathrm{R} / \mathrm{C}$ frame structures (as represented by the tested specimen) the second order effects need not be taken into account.

The damage limitation requirement prescribes the limits of interstorey drift as follows:

$$
d_{r} v \leq 0.010 h
$$

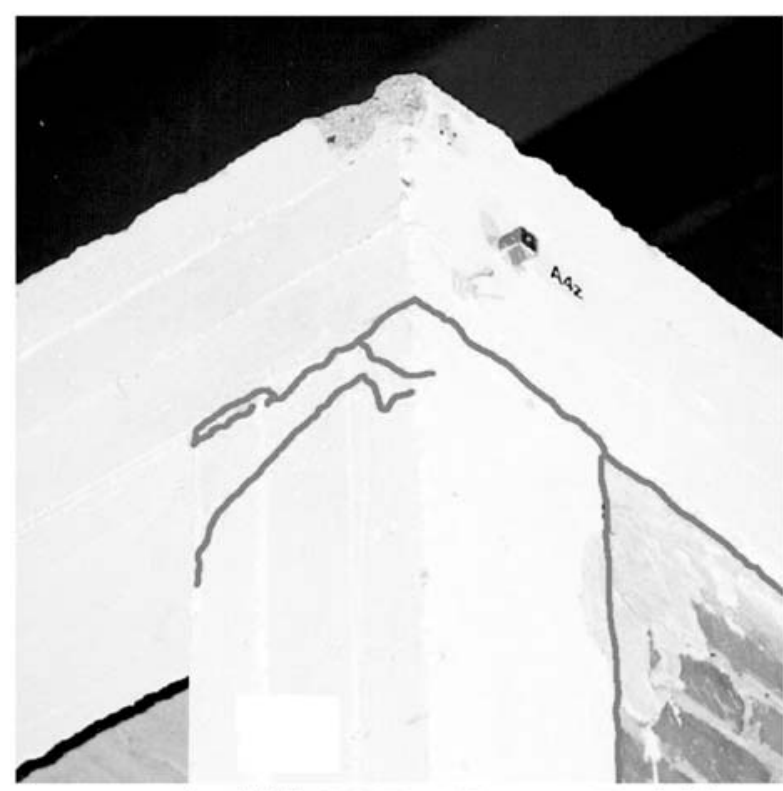

after T25, 6DOF, 4dB, max $a T x=1.13 \mathrm{~g}$

Fig. 9 Cracks in critical sections of $R / C$ frame at the end of test - top of the frame provided that the non-structural elements are fixed in a way so as not to interfere with structural deformations, or there are no nonstructural elements.

Taking the value $v=0.5$ and the largest reached value of $d_{r}$, there is for $y$-direction:

$$
0.05347 \times 0.5 / 2.8=0.0095<0.01
$$

which suggests that the first storey drifts remained just below the limit value.

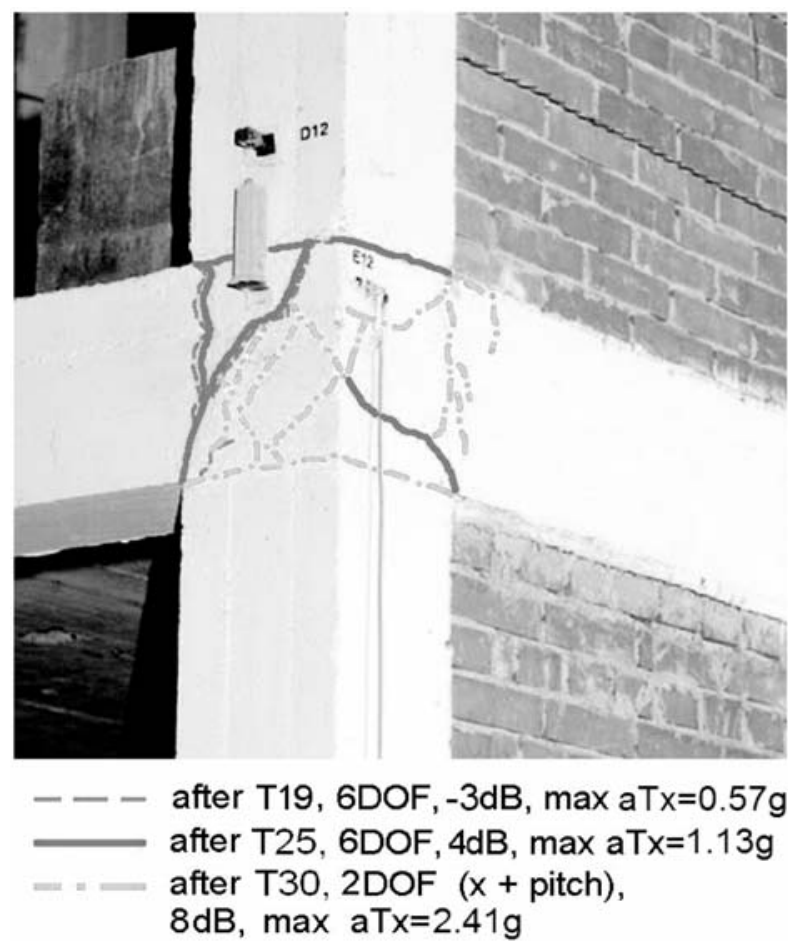

Fig. 10 Cracks in critical sections of $R / C$ frame at the end of test - frame joint at the first floor 


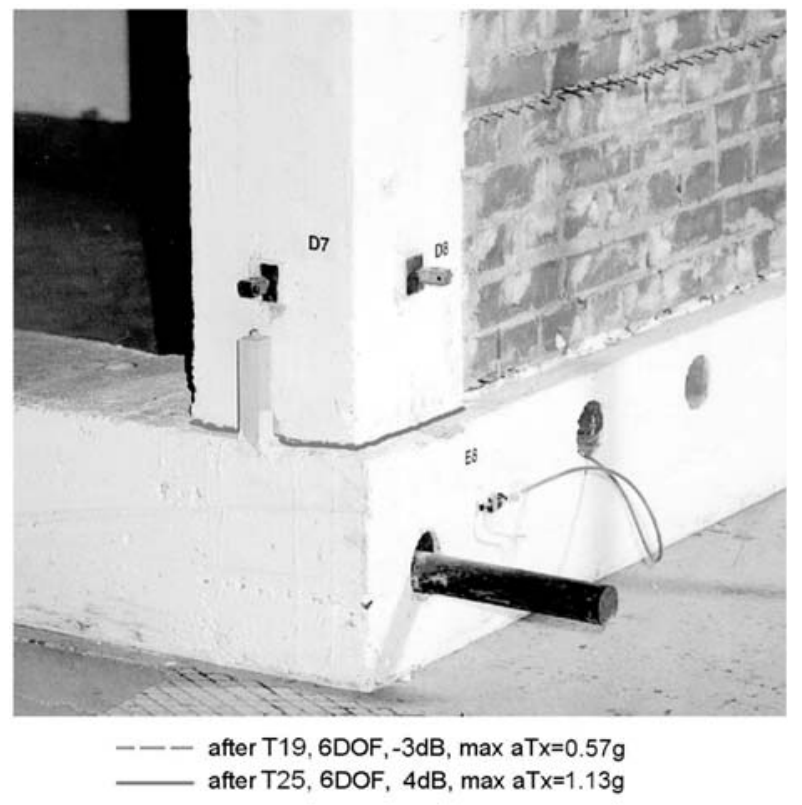

Fig. 11 Cracks in critical sections of $R / C$ frame at the end of test - frame joint at the base
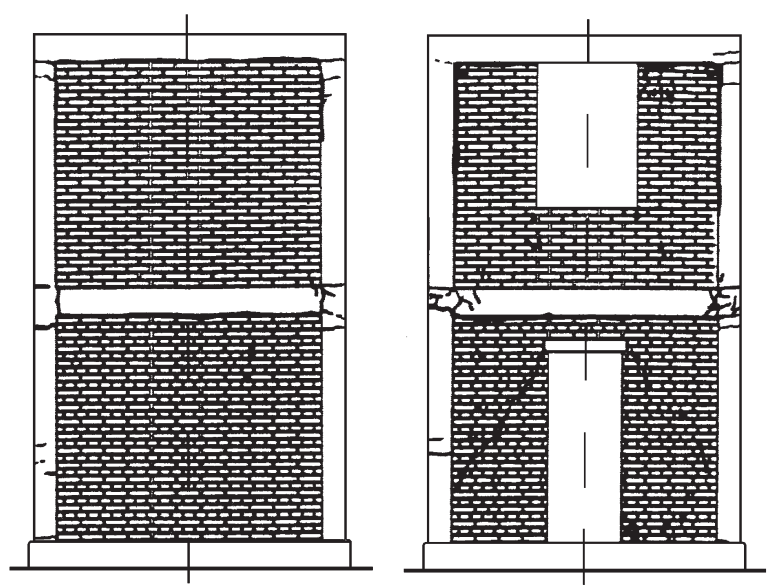

Fig. 12 Cracks in masonry at the end of test: left - solid wall; right - wall with openings

\section{Using of pushover approach in the test data analysis}

The pushover analysis applies the static non-linear analysis for determining the dependence between the base shear force and control displacement of a structure. The control displacement may be taken at the centre of mass of the roof of the building (see EN 1998-1: 2004 or FEMA 273: 1997). The lateral load is considered like distributed in the first modal shape. A similar approach can be applied in the test data analysis. Having in mind the inertial forces acting during the seismic response, distribution of masses and data about response acceleration and displacement, experimental control parameters could be determined for different states of the speci- men during execution of seismic tests. Tests T19, T25 and T30 were the subject of such analysis.

Accelerations were measured in points as shown in Figure 8. The allocation of concentrated masses to sensor points at the floor levels and respective horizontal direction follows the known rule used for calculation of concentrated masses for multi mass dynamic models. The relations between seismic input and maximum absolute acceleration in $x$ and $y$ directions indicate the non-linear response effects (Figure 13). Similar charts for relations between seismic input and maximum relative displacement are in Figure 14.

The relation between the control displacement (roof horizontal displacement) and the base shear can be calculated on the basis of a built analytical model, using changes in non-linear stiffness, e.g. according to FEMA 273 or EN 1998-1, see Fig. 15.

Actual relation between the mean top relative displacement of the tested specimen and the base shear force is given in Figure 16. Such development of the base shear is interconnected with the reached maximum strains in critical sections and reached interstorey drifts, see Tables 3 and 4. Fig. 16 illustrates the clear distinction between the base shear force capacity in $y$-direction (the resistance is mobilised only by $\mathrm{R} / \mathrm{C}$ frame) and in $x$-direction (the resistance is mobilised both by $\mathrm{R} / \mathrm{C}$ frame and masonry infills supported by horizontal polymer grids).

The test T25 significantly participated in the softening of a system, the crack widths, strains, the increasing and deterioration of the frame and masonry. However, polymer grids in bed joints supported the integrity of a system and prevented it from a significant damage. Even if these grids are locally fixed to the $\mathrm{R} / \mathrm{C}$ frame, the system exhibits reasonable behaviour under higher near field seismic inputs. Reference changes of natural frequencies with the use of Figs. 15 and 16 and rules of FEMA 273 are in Table 1, giving a reasonable agreement with the measured values.

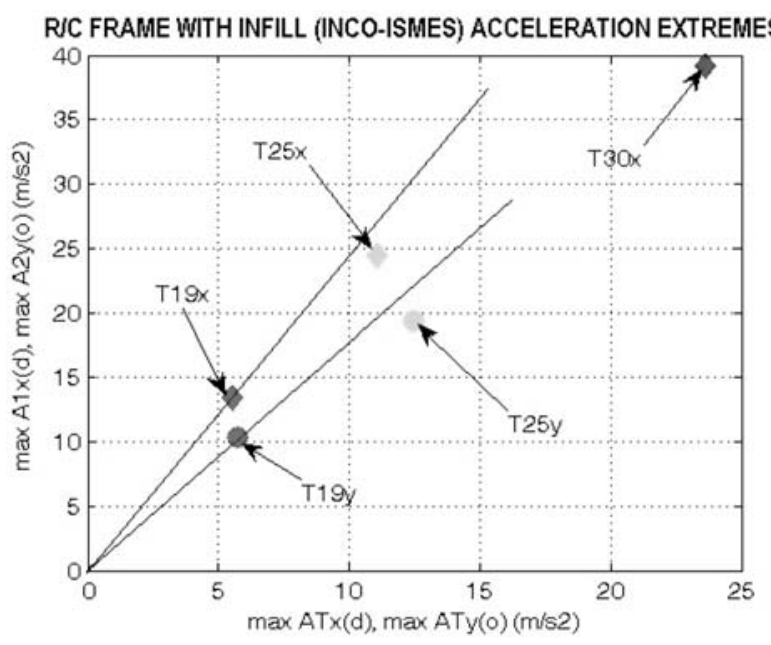

Fig. 13 Absolute accelerations at the top of frame versus seismic input (Tests 19, 25, 30) 
It should be mentioned that the lower bound of yield stress of used steel rebars was $490 \mathrm{MPa}$, the yield strain was above 50 milistrain and strength was $590 \mathrm{MPa}$ with ductility of 150 milistrain. The compression strength of concrete was $30 \mathrm{MPa}$. Considering these data and strain in tension rebars of value 10 milistrain, the theory for concrete column resistance gives the calculated value of base shear $186 \mathrm{kN}$ for $y$-direction and test T25. The agreement with Fig. 16 and inertial forces is evident.

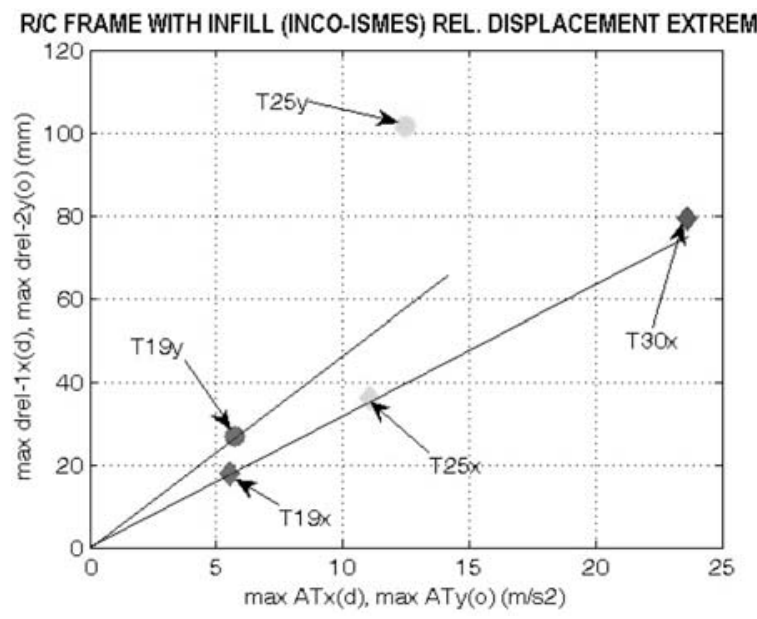

Fig. 14 Relative displacements at the top of frame versus seismic input (Tests 19, 25, 30)

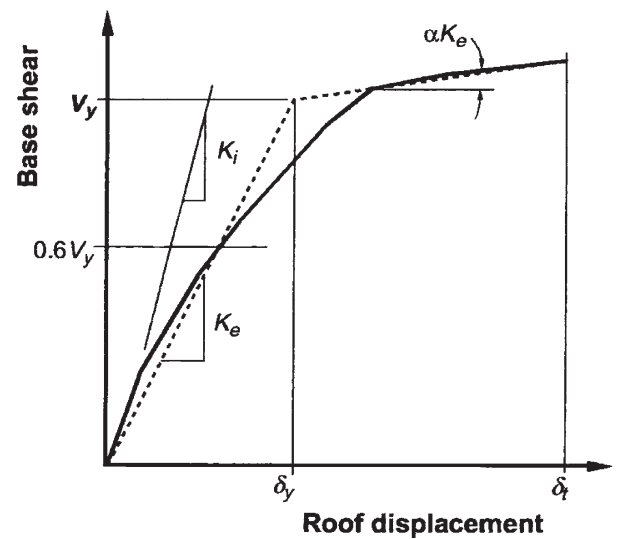

Fig. 15 FEMA 273 dependences between top displacement and base shear for pushover analysis

\section{Conclusions}

The tests of a full scale model on a large shaking table were realised using the original, appropriately modeled 6DOF seismic input based on actual strong earthquake. The numerous obtained data describe redistribution of seismic resistance between $\mathrm{R} / \mathrm{C}$ frame, masonry infills, boundary joints and the polymer grid reinforcement in the masonry infills.
RIC FRAME WITH INFILL (INCO ISMES) top Displ I base Shear EXTREMES

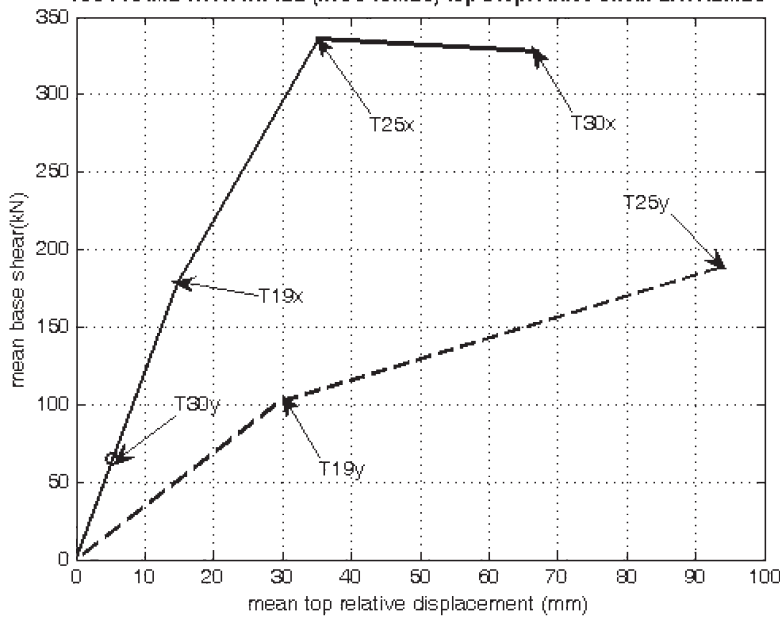

Fig. 16 Relations between the top relative displacements and base shear of tested frame (Tests 19, 25, 30)

The space seismic response differs from the plane one. Therefore, both the structural model and inputs should be built in a space mode. Such an approach implies changes in natural frequencies and modes of vibration. Different positions of initiative failure regions should be expected in relation to the used structural model and inputs.

The necessity of the continuous control of seismic resistance capacity in critical parts of the structure should be emphasised. Simultaneously, the appropriate changes should be introduced into the structural model depending on the degree of its non-linear behaviour. The verifications of stresses in critical parts give the answer whether the design is sufficient or should be modified. The described case study proved that it is possible to reach such a combination of the reinforced frame with infill masonry walls which gives nearly uniform seismic resistance capacity and remarkable contribution of infills to total seismic resistance of structure.

The tools which are used in response analysis and the knowledge from experimental research should be reasonably applied to improve the structure resistance capabilities. If ductility is supposed to be beneficial, the cracks can be accepted provided that neither loss of structure integrity nor instability can appear. The proper detailing and the appropriate measures for increasing the total resistance capacity are the key design and execution activities in construction industry. The described technology underlines an integrity role in the increase and securing dynamic resistance capacity. To this end, not only safety aspects in case of natural or terrorist hazards, but also protection against undesirable transport effects and settlements can be reasonably and conveniently solved.

\section{Acknowledgements}

The research was mainly funded by EC in the framework of Environmental INCO COPERNICUS Studies and partially by VEGA Project $2 / 7114 / 27$. The financial support is gratefully acknowledged. 


\section{References}

[1] ANIČIĆ, D., FAJFAR, P., PETROVIĆ, B., SZAVITS-NOSSAN, A. and TOMAŽEVIĆ, M. (1990), Earthquake Engineering, Gradevinska knjiga, Beograd.

[2] BAIRRAO, R., FALCAO SILVA, MJ., JUHÁSOVÁ, E., CAMPOS COSTA, A., COELHO, E. (2006), Shaking table tests of an asymmetrical limestone building. Proceedings of the 1st European Conference on Earthquake Engineering and Seismology, Geneva, Switzerland, Sept. 3-8, 2006; p. 636/1-10.

[3] COLOMBO A., NEGRO P. (2000), Advanced materials for strengthening, rehabilitation and repair of structures. Experimental activities at ELSA, In: Mitigation of Seismic Risk Support to Recently Affected European Countries, Proc. of Workshop held in Belgirate, Italy in 27-28 Nov. 2000, JRC EC Ispra, 2000; p. 5/1-7.

[4] Eurocode 8, EN 1998-1: 2004, Design of Structures for Earthquake Resistance. Part 1. General Rules, Seismic Actions and Rules for Buildings, CEN, Brussels.

[5] FEMA 273: 1997, NEHRP Guidelines for the Seismic Rehabilitation of Buildings. BSSC, Washington, October 1997.

[6] HÁJEK, J. (1994), Deformations of Concrete Structures. VEDA, Bratislava.

[7] JUHÁSOVÁ, E. (1991), Seismic Effects on Structures. Elsevier, Amsterdam.

[8] JUHÁSOVÁ, E. (1999), Seismic effects on R.C. frames with infills including torsion input, Structural Dynamics, Eurodyn '99, 1999, Praha, Balkema, Rotterdam, p. 1147-1152.

[9] JUHÁSOVÁ, E. (2004), Effect of structural integrity in improving the resistance to dynamic loads - some studies. Journal of Struct. Engng., India, Vol. 31, No. 1, p. 65-72.

[10] JUHÁSOVÁ, E., SOFRONIE, R, CONTRI, P. (2000), Real time testing of reinforced infills. In: Proceedings of 12WCEE Auckland 27, Jan. - 3, Feb. 2000, p. 921/1-8.

[11] JUHÁSOVÁ, E., SOFRONIE, R., JUHÁS, M. (2004), The key role of structure integrity and new materials. Proceedings of the Conference Building for European Future, Maastricht, October 14-15, 2004, ECCREDI, Brussels, Vol. 1, p. 527-544.

[12] PAUlAY, T., PRIESTLEY, M.J.N. (1992), Seismic Design of Reinforced Concrete and Masonry Buildings. John Wiley \& Sons, New York.

[13] SOFRONIE R., JUHÁSOVÁ E. , GREENING P. (2003), Seismic strengthening of masonry, SECED Newsletter, Vol. 16, No. 4, May 2003, p. 6-7. 